\title{
Determination of College Expectations in OECD Countries: The Role of Individual and Structural Factors*
}

\author{
PETR MATĚJŮ, MICHAEL L. SMITH, PETR SOUKUP, and JOSEF BASL** \\ Institute of Sociology, Academy of Sciences of the Czech Republic, Prague
}

\begin{abstract}
Renowned international experts in higher education financing have argued that, owing to large government deficits, tertiary education will not be able to open up and meet growing demand unless cost-sharing principles and efficient student financial aid programmes are introduced. Opponents of cost-sharing in higher education object that introducing tuition fees will raise inequality in access to higher education. Drawing on OECD data, and focusing on college expectations, the authors argue that the effects of ability, gender, and socio-economic background on college expectations are primarily shaped by the characteristics of secondary education systems, such as the degree of stratification and vocational specificity of secondary schools, while the principal characteristics of the tertiary education system, such as enrolment rates and the model of financing, play a much less important role. The results clearly show that, after controlling for the effects of secondary school system characteristics, cost-sharing, as such or by degree, does not affect the formation of college expectations by ability, gender, and socio-economic background as much as the selectivity of the secondary school system does.
\end{abstract}

Keywords: higher education, aspirations, ability, inequality, selectivity Sociologický časopis/Czech Sociological Review, 2007, Vol. 43, No. 6: 1121-1148

\section{Introduction}

Adolescents' aspirations and expectations influence not only what they choose to study in school but also how they prepare for life as adults and ultimately the kinds of careers they embark on. Since aspirations serve as an important link between an adolescent's social origin and the educational and occupational careers

\footnotetext{
* Research for this article was made possible by the gracious support of the Czech Ministry of Labour and Social Affairs, grant no. 1J 005/04-DP2 ‘Unequal Access to Education: The Extent, Sources, Social and Economic Consequences, Policy Strategies'. Work on this paper was also made possible by a grant from the Fulbright Commission, awarded to the article's first author under the New Century Scholars 2007-2008 programme titled 'Higher Education in the 21st Century: Access and Equity'.

** Direct all correspondence to: Petr Matějů, Institute of Sociology, Academy of Sciences of the Czech Republic, Jilská 1, 11000 Prague 1, Czech Republic, e-mail: petr.mateju@soc. cas.cz.
}

(C) Sociologický ústav AV ČR, v.v.i., Praha 2007 
they may pursue, one of the liveliest areas of research in social stratification has naturally been the study of aspirations. Most such studies have produced significant evidence about the role of social origin, ability, and school context in shaping aspirations. Growing attention has also been given to the role of the institutional context. However, much of the research on the impact of education systems on aspirations and expectations has been based on a small sample of countries, which limits the generalisability of their findings and prevents sociologists from being able to better weigh the importance of different factors in shaping educational aspirations around the world.

Our study contributes to this body of knowledge by analysing the role of specific features of education systems in shaping college expectations using data from the PISA 2003 project. ${ }^{1}$ The analysis involved a number of steps. First, by drawing on concepts proposed in previous research on the relationships between aspirations and the structural characteristics of education systems, we created composite variables (dimensions) representing the degree of stratification and vocational specificity of the secondary education system on the one hand, and the permeability, openness, and financing of tertiary education on the other. Next, we used PISA 2003 data to conduct individual-level logistic regressions of college expectations on parental socio-economic status (SES), child's measured ability, and gender to assess the degree to which they determine college expectations. The results of the logistic regressions are then entered into the analysis of the relationships between the degree of stratification, openness, and selectivity in the education system on the one hand, and the degree to which they determine college expectations on the other.

\section{Prior research on the role of social-psychological and structural factors in the formation of educational aspirations and expectations}

From the very outset social stratification research has produced overwhelming evidence that the educational aspirations of adolescents are one of the strongest predictors of educational and occupational careers [Hyman 1953; Reissman 1953; Kahl 1953; Herriott 1963]. Since the early 1950s, the development of pupils' aspirations has been one of the most frequent topics in research on social stratification and the inter-generational transmission of social status. Thus, by the early 1970s, Williams [1972] was able to identify more than four hundred studies relating to educational aspirations alone. By 2004 as many as 1100 articles on this topic had been published in professional journals alone. ${ }^{2}$

\footnotetext{
${ }^{1}$ PISA (Programme for International Student Assessment ) is the largest cross-national comparison of adolescents to date. A total of forty-one countries participated in the survey in 2003, of which thirty were OECD member states.

2 According to the EBSCOhost research database.
} 
Many of the pioneering studies on educational aspirations that significantly influenced further research on social stratification, inequality, and mobility emerged from the work of William H. Sewell and his colleagues, who laid the foundations of the so-called social-psychological school in social stratification research (Archibald O. Haller, Vimal P. Shah, Alejandro Portes, Otis D. Duncan, Robert M. Hauser, to name some of its most important figures). To explain the variance in the educational aspirations of adolescents, early studies by these scholars [Sewell, Haller and Straus 1957; Sewell 1961, 1963; Sewell and Hauser 1972; Sewell and Shah 1967; Sewell and Shah 1968a, 1968b] pointed to such factors as parental SES, measured ability, academic performance, parents' expectations and encouragement, and peers' aspirations, to list just a few.

The late 1960s saw the introduction of a new impetus into research on aspirations, particularly owing to the seminal contribution of Peter Blau and Otis D. Duncan [1967; Duncan 1968], whose model of the social stratification process offered a new theoretical and methodological context for research. Partly in response to the simplicity of the original Blau-Duncan model, aspirations - previously studied primarily as a dependent variable - were placed at the very centre of the so-called Wisconsin social-psychological model [Sewell, Haller and Portes 1969; Sewell, Haller and Ohlendorf 1970; Hauser 1972; Sewell and Hauser 1972, 1975; Hauser, Tsai and Sewell 1983]. Based on the extensive Wisconsin Longitudinal Study, Sewell, Hauser and their colleagues demonstrated that educational aspirations - shaped primarily by measured ability, academic performance, parental SES, teachers and peers - play the key role in explaining later educational and occupational attainment. In this sense, educational aspirations have become 'the strategic centre of the model' [Haller and Portes 1973: 68].

Over time, other approaches to the study of educational aspirations eventually challenged some of the core assumptions in the social-psychological model. Alan C. Kerckhoff, in his first critical analysis of the 'socialisation model' [Kerckhoff 1976], emphasised that even though scholars who subscribed to the socialisation perspective achieved impressive results in their explanations of the processes of educational and occupational attainment, they did not pay adequate attention to the structural constraints that individuals take into account (more or less consciously) when making important decisions about their future educational and occupational careers. As a result, Kerckhoff argued, the social-psychological model left a good deal of the variance in aspirations unexplained [Kerckhoff 1976].

Therefore, without questioning the true achievements of the research carried out under the socialisation perspective, the advocates of the 'allocation' perspective [Kerckhoff 1976; Kerckhoff and Campbell 1977a, 1977b; Wilson and Portes 1975; Simmons and Rosenberg 1971; Alexander and Eckland 1975; Karabel and Astin 1975; Jencks 1972; Han 1968, 1969] suggested that the research on aspirations and their role in the attainment process underestimated how contextual and institutional conditions influence the way pupils' unconstrained 'wishes' transform into 'realistic' plans. The allocation model was not intended to replace 
the socialisation model, but was rather meant to draw into consideration other factors that could help explain the attainment process and, in particular, the formation of educational aspirations. 'The socialization model interprets the strong association between ambition and attainment as indicating that the goals direct and motivate the child's efforts during the formative years and thus determine the level of attainment he reaches later. (..) this interpretation implies an open system within which the major determinants of attainment are motivation and ability. (...) It seems reasonable to argue that expectations of the future are affected by observed structural constraints, and thus they reflect more than pure motivation.' [Kerckhoff 1976: 371]

The real impact of education systems on the formation of educational aspirations can only be properly assessed in a cross-national comparative analysis. One of the first comparative analyses of the formation of aspirations was Kerckhoff's study [1977] of thirteen-year-old boys in the United States and England, which built on the distinction between 'contest' and 'sponsored' mobility proposed earlier by Turner [1960]. Following Turner's argumentation, Kerckhoff pointed out that the English education system forced adolescents to make irreversible decisions about their educational careers. ${ }^{3}$ Both authors noted that the American system was much more open to the 'contest' type of mobility, 'providing more opportunity for adolescents to change course throughout secondary school and encourages the belief that such a change is possible' [Kerckhoff 1977: 564]. Thus, as Turner concludes, 'the earlier that selection of elite recruits is made, the sooner others can be taught to accept their inferiority and to make 'realistic' rather than fantasy plans' [Turner 1960: 859].

Kerckhoff's comparative analysis confirmed that social origin and ability played a greater role in explaining educational aspirations among English boys than among their American counterparts. In interpreting these results, in line with Turner's argument, Kerckhoff attributed the more structurally constrained aspirations in England, compared to the US, to the greater 'realism' of English pupils and the English system's emphasis on ability for determining which type of secondary school a pupil would attend. While the English system leads pupils to develop realistic educational and occupational plans earlier in life, the American system does not provide the same structural constraints, and thus pupils maintain lofty aspirations until late in the educational process, that is, as high school graduation nears and realistic assessments of career options need to be made.

Educational aspirations are therefore shaped not just by factors at the individual or social-psychological level (e.g. parental SES, measured ability) and at the contextual level (e.g. the quality and type of schools attended) but also at the structural level of the education system. Research on the role of education

\footnotetext{
${ }^{3}$ At the age of eleven or twelve, English boys had to choose between the 'elite' grammar school, which had a more demanding and academically oriented curriculum preparing students for post-secondary education, and the more popular, and academically less demanding, 'secondary modern school'.
} 
systems on educational aspirations has been largely based on the typology of systems introduced by Müller and Shavit [1998] and further elaborated by Kerckhoff [2001]. The typology is based on three dimensions according to which education systems can be classified: the degree of stratification in the education system, the system's orientation towards vocational training (vocational specificity), and its standardisation.

'Stratification', most often used to classify secondary schools, 'refers to the degree to which systems have clearly differentiated kinds of school whose curricula are defined as "higher" and "lower". (...) In stratified systems, the program offerings in the types of secondary schools are associated with different degrees of access to opportunities for additional, more advanced schooling. So, the term stratification refers to both the kind of programs offered and their links to future opportunities' [Kerckhoff 2001: 4]. 'Vocational specificity', another relevant dimension used often in analyses of education systems, is the degree to which curricula are designed to prepare students for particular vocations. In terms of statistical indicators, it can be represented by the proportion of students leaving the education system with specific skills [e.g. Buchmann and Dalton 2002]. A high degree of vocational specificity very often indicates also a high degree of system stratification, because schools providing training for specific occupations usually co-exist with schools preparing for further, more academic types of education at a higher level. In other words, high vocational specificity goes hand in hand with high stratification, usually within the so-called dual system of secondary education, such as that in Germany. 'Standardisation' refers to the degree to which governments create the conditions (e.g. teachers' education, education financing, etc.) and the control mechanisms (nationwide testing, school-leaving examinations, etc.) to achieve certain standards of quality in the education provided by different schools.

The above-mentioned classification of education systems, together with the highly standardised statistical data on education systems published every year by the OECD in its Education at a Glance, and data from large-scale comparative surveys of adolescents assessing various aspects of their ability and skills, socio-economic background, values, and aspirations (such as TIMSS, PISA, and PIRLS), all provide exceptionally strong empirical evidence that enables the use of multilevel analytical strategies to explain educational aspirations in different institutional settings and societal contexts. In other words, these very rich sources of data can be used to explain the formation of educational aspirations and educational attainment by factors on different analytical levels: individual (parental SES, measured ability), contextual (school level differentiation), and structural (institutional characteristics of education systems).

Research on the interplay between the individual, contextual and structural levels in the formation of educational aspirations has already brought valuable results. Buchmann and Dalton [2002] used data from one of the large-scale student assessment projects [TIMSS 1995] to identify differences between selected countries in the effect of parents' and peers' attitudes towards education on the 
educational aspirations of thirteen-year-olds. First, the study has confirmed that, after controlling for the effect of ability (math achievement), the effect of parents' education on the educational aspirations of adolescents is significantly higher in countries with highly stratified education systems than in countries with relatively undifferentiated systems of secondary education. Conversely, the attitudes of parents and peers towards education more significantly affect the educational aspirations of adolescents in countries with less stratified systems. The authors, though they acknowledge that their evidence is not strong, come to the conclusion that in more differentiated systems aspirations are largely determined by the type of school students attend, so there is little room for interpersonal effects [Buchmann and Dalton 2002: 99].

Special attention has to be paid to differences in educational aspirations and expectations between schools, whether resulting from the formal stratification of schools (i.e. due to the existence of different types of schools at a secondary level), from tracking within schools of the same type, or just from differences in the quality of schools not associated with any formal school classification. While differences in student achievement according to type of school were recently studied in a cross-national comparative perspective, thanks to the PISA assessments [see, e.g., OECD 2005c], cross-national differences in between-school variance still await a thorough analysis. Like school performance, differences in educational aspirations between schools are also often attributed to differences in the socio-economic background of students, especially in highly stratified systems.

But even in quite comprehensive systems there are mechanisms through which schools develop specific educational settings, and these affect the further aspirations of students. In many countries, for example, the choice of school may effectively homogenise the socio-economic composition of the student body; the socio-economic composition may also be determined by the school's geographic location, with wealthy neighbourhoods being served by schools that tend to have higher levels of student performance, but also higher educational aspirations. Therefore, even in more universal school systems, parents with higher socio-economic status may find the means to send their child to better schools. Technically, multi-level analysis can reveal this effect, by separating the so-called intraclass correlation, which indicates the degree to which aspirations vary between schools. We may assume that in highly stratified or tracked education systems the intra-class correlation for college aspirations will be much larger than in less stratified systems, but even there, owing to processes mentioned above, it can be quite large.

The aim of this paper is to go a step further in the empirical elaboration of the relationships between educational expectations and the institutional characteristics of education systems. More specifically, in the first step, statistical data portraying systems of secondary and tertiary education in OECD countries are used to assess the relevant structural characteristics of education systems (degree of stratification, vocational specificity, selectivity, openness, etc.). In the second 
step, survey data from the OECD international student assessment [OECD 2005a, $2005 \mathrm{~b}$ ] are analysed to assess the degree to which the college expectations of fifteen-year-olds are determined by measured ability, gender, and socio-economic background. Finally, in the third step, the results from the previous two steps are entered into a set of regression analyses carried out again at the country level, designed to test hypotheses about the role of relevant education system characteristics - such as secondary school system openness, enrolment rates in tertiary education, the principal characteristics of the system's financing - in how college expectations are determined by ability and socio-economic background.

\section{Hypotheses, data, analytical strategy, and methodology}

\section{Assumptions and hypotheses}

The existing evidence from comparative research on education systems [Müller and Shavit 1998; Kerckhoff 2001; Buchmann and Dalton 2002; OECD 2006] allows us to build on two assumptions regarding the relationships between the structural characteristics of secondary and tertiary education:

A1: The degree of stratification and vocational specificity are two closely related characteristics of secondary education systems;

A2: The openness and permeability of secondary education is strongly associated with the openness of tertiary education.

These two assumptions will be verified on recent OECD data, and the results of the verification process (principal component analysis) will be used to define composite variables for use in further analysis of the determination of college expectations.

Drawing on previous comparative research on the institutional embeddedness of college expectations, four main hypotheses can be formulated for analysis:

H1: The more open the secondary system, the less college expectations are determined by social origin, ability and gender. The same applies to the overall openness of the education system.

H2: The effects of ability and socio-economic background on college expectations are shaped more by the openness of the secondary system than by the openness of the tertiary system.

H2a: Between-school variance is the most important characteristic of the secondary education system affecting the degree to which college expectations are determined by ability and socio-economic background. Such 
variance can stem from either formal system stratification (the existence of different types of schools, tracking, etc.) or other, less apparent, processes (school choice, within school tracking, etc.). By controlling for between-school variance (represented by the intra-class correlation), the effects of other characteristics of the secondary school system can largely be eliminated.

$\mathrm{H} 2 \mathrm{~b}$ : After controlling for the effect of the openness of the secondary education system the effects of tertiary education enrolment, of the share of tuition fees in financing tertiary education, and of financial aid to students on how much college expectations are determined by ability and by socio-economic background should not be significant.

\section{Data}

Statistical data used to describe education systems and to define relevant dimensions of their stratification come from the OECD yearbook Education at a Glance [OECD 2003, 2004, 2005d, 2006]..$^{4}$ This rich source of data provides information about the basic characteristics of education systems, access to education, participation and progress, financial and human resources invested in education, the learning environment, and the organisation of schools, etc. Most of the indicators published in the 2005 edition of the yearbook describe the situation in 2003, when the PISA 2003 survey data was collected in participating countries.

Two sets of statistical indicators were used to describe the education systems in individual countries in terms of their stratification, openness, and permeability. The following four indicators were used for secondary education: ${ }^{5}$

a) GENSEC: Upper secondary education enrolment in general education programmes (2003)

b) NUMPRG: Number of school types or distinct educational programmes available to fifteen-year-olds (2003)

c) VOCAT: Proportion of fifteen-year-olds enrolled in programmes that give access to vocational studies at the next level of education or direct access to the labour market (2003)

d) EXPSEC: Expenditure on educational institutions of primary, lower secondary, and primary education as a percentage of GDP from public and private sources (2002)

\footnotetext{
${ }^{4}$ Some indicators that were not available in the most recent edition of Education at a Glance (2006) were obtained from earlier editions (2003, 2004, and 2005).

5 The acronyms for the statistical indicators (i.e. the names of the variables used in the analyses) and the values of indicators in individual countries are displayed in Table A1 in the Appendix.
} 
Four variables were also used to indicate the openness of the tertiary education system:

a) ENROL: Net entry rates into tertiary education (2003)

b) PRVRSC: Relative proportion of private sources of funding on institutions of tertiary education (percentage of total expenditure - 2002)

c) FINAID: Financial aid to students: public subsidies for households and other private entities as a percentage of total public expenditure on tertiary education (percentage of total expenditure on tertiary education - 2002)

d) EXPTER: Expenditure on tertiary educational institutions as a percentage of GDP from public and private sources.

The international data file from the PISA 2003 was used to test our hypotheses about the determination of college expectations by ability, parental socio-economic status, gender, and type of school. Although the PISA 2003 focused mainly on mathematical literacy, it also tested three other dimensions, namely reading literacy (covered mainly in the PISA 2000), science literacy (covered mainly by the PISA 2006), and problem solving. The target population of the PISA surveys is fifteen-year-olds enrolled in school, regardless of the grade or type of institution in which they are enrolled.

The PISA surveys use a two-stage stratified sampling design. At the first stage, schools are sampled systematically from a comprehensive national list of all eligible schools with probabilities that are proportional to a measure of size. ${ }^{6}$ Within sampled schools, students are selected with equal probability from a list of fifteen-year-old students in each selected school. ${ }^{7}$ From the forty-one OECD and non-OECD countries participating in the 2003 PISA data collection, for our comparative analysis we selected only thirty OECD countries for which we can also obtain statistical data regularly published in the OECD statistical yearbook Education at a Glance [OECD 2006].

The following variables were used in analyses based on data from PISA 2003:

a) COLLEXP - expectations to attain tertiary (i.e. college or university) education $(0=$ no, $1=$ yes $) ;$

b) $\operatorname{SEX}(1=$ female, $2=$ male);

\footnotetext{
${ }^{6}$ The measure of size was a function of the estimated number of eligible fifteen-year-old students enrolled. Individual schools in which students in this age can be enrolled were selected systematically with probabilities proportional to size, the size being a function of the estimated number of eligible (fifteen-year-old) students enrolled.

${ }^{7}$ See Chapter 4 of Education at a Glance [OECD 2005c] for a detailed description of the PISA sampling procedures and target population coverage.

8 This means category 5 or 6 in the ISCED coding.
} 
c) HISEI - the highest parental occupational status; ${ }^{9}$

d) ABIL - index of measured ability (derived from five plausible values for each literacy domain). ${ }^{10}$

\section{Analytical strategy and methodology}

To define composite variables representing the stratification, vocational specificity, permeability, and openness of the education system, we applied a factor analysis of the OECD statistical indicators to the data for the subset of OECD countries participating in the PISA 2003. To assess the degree of determination of college expectations at the country level for each OECD country in the PISA 2003 data set (thirty countries out of forty-one participating in the PISA 2003), we conducted a logistic regression of college expectations (COLLEXP) on parental socioeconomic status (HISEI), child's measured ability (ABIL), and gender (SEX). The individual regression coefficients and the standardised (centred) coefficients of determination (Nagelkerke's $R^{2}$ ) for these countries were then entered into the analysis of the relationships between the stratification, openness, and selectivity of education systems on the one hand, and the degree of determination of college expectations on the other. Finally, we regressed the above variables that determine college expectations (ABIL, HISEI, Nagelkerke's $\mathrm{R}^{2}$ ) on the most important characteristics of secondary and tertiary education systems.

For reasons discussed above, we computed the intra-class correlation (ICC), which in this case indicates the degree to which college expectations vary between schools. Statistically, the intra-class correlation takes between-school variance in expectations as a proportion of their total variance. The general formula for $\mathrm{ICC}_{0}$ is:

\footnotetext{
${ }^{9}$ Occupational data for both the student's father and the student's mother were obtained by asking open-ended questions. The responses were coded into four-digit ISCO codes and then recoded to the international socio-economic index of occupational status (ISEI) [Ganzeboom et al. 1992]. HISEI corresponds to the higher ISEI score of either parent or to the only available parent's ISEI score. Higher ISEI scores indicate higher levels of occupational status.

${ }^{10}$ Students' achievements in mathematics, reading, science, and problem solving are reported on standardised composite scales (the average score is 500 , standard deviation is 100 across all students in OECD countries in the PISA). Since the creation of scales was based on Item Response Theory, the data set contains five plausible values for each student instead of one fixed value. When achievement scores are used in analyses as dependent variables, all five plausible values should be used simultaneously to obtain the estimates of population parameters [OECD 2005b]. We use achievement scores only as independent or control variables, so the scale of 'ability' could have been created by averaging five plausible values for each literacy domain (obtaining four variables: MATH for mathematics, READ for reading, SCIE for science, and PROB problem solving) and computing an additive scale (MATH + READ + SCIE + PROB/4). The analysis of reliability confirmed that these variables clearly form one scale (Cronbach's $\alpha=0.9672)$.
} 


$$
\mathrm{ICC}_{0}=\frac{\sigma_{\mathrm{u}}^{2}}{\sigma_{\mathrm{e}}^{2}+\sigma_{\mathrm{u}}^{2}},
$$

where $\mathrm{ICC}_{0}$ is the intra-class correlation for the null model, $\sigma_{\mathrm{u}}^{2}$ is the variance at the second (school) level, and $\sigma^{2}$ is the variance at the first (individual) level. Since the college expectations variable is binary, we applied a slightly different formula (see, e.g., Snijders and Bosker [1999]):

$$
\mathrm{ICC}_{1}{ }_{11}=\frac{\sigma_{\mathrm{u}}^{2}}{\pi^{2} / 3+{\sigma^{2}}^{2}}
$$

where $\pi^{2} / 3$ is the variance at the first level, and $\sigma_{\mathrm{u},}^{2}$ is the variance at the second level.

The first step of the analysis involved thirty logistic regressions on data from the PISA 2003 (i.e. separately for each country), ${ }^{12}$ aimed at assessing the net effects of measured ability, parental socio-economic status, and gender on college expectations, as well as the overall degree of determination of college expectations by these three variables (Nagelkerke's $R^{2}$ ). The second step of the analysis was designed to explain the differences between countries in the coefficients of determination (Nagelkerke's $\mathrm{R}^{2}$ ) and in the regression coefficients associated with the variables ABIL and HISEI using indicators describing the education systems of individual nations.

To achieve this goal, two sets of regression analyses were performed with three equations in each. The first set included an equation for the overall determination of college expectations by ability, socio-economic background, and gender (dependent variable ZDETEXP), while the other two equations estimated the effect of ability and socio-economic background on expectations (dependent variables RCABIL and RCISEI): ${ }^{13}$

$$
\begin{aligned}
& \text { ZDETEXP }=a+b_{1}{ }^{*} \text { SCND }+b_{2}{ }^{* T E R T} \\
& \text { RCABIL }=a+b_{1}{ }^{*} \text { SCND }+b_{2}{ }^{*} \text { TERT } \\
& \text { RCHISEI }=a+b_{1}{ }^{*} \text { SCND }+b_{2}{ }^{* T E R T ~}
\end{aligned}
$$

The second set of equations tested both the gross and the net effects of specific characteristics of the tertiary education system on the determination of college expectations:

\footnotetext{
${ }^{11}$ Snijders and Bosker use the symbol $\rho_{\mathrm{i}}$ instead of our ICC $\mathrm{C}_{\mathrm{i}}$ [Snijders and Bosker 1999: 224].

${ }^{12}$ See the Appendix for the SPSS syntax for the logistic regressions.

${ }_{13}$ These variables are the values of the standardised regression coefficient from the logistic regression of aspirations on ability, socio-economic background, and gender.
} 
ZDETEXP $=\mathrm{a}+\mathrm{b}_{1}{ }^{*}$ SCND $+\mathrm{b}_{2}{ }^{*}$ ICC $+\mathrm{b}_{3}{ }^{*}$ ENROL $+\mathrm{b}_{4}{ }^{*}$ PRVRSC $+\mathrm{b}_{5}{ }^{*}$ FINAID

where ICC is the intra-class correlation for college expectations, SCND and TERT are the factor scores for openness of secondary education and tertiary education respectively, ENROL is the net entry rate into tertiary education, PRVRSC is the relative proportion of private sources of funding in institutions of tertiary education (representing the actual role of tuition fees in financing tertiary education), and FINAID is the financial aid to students defined as public subsidies to households and other private entities as a percentage of total public expenditure on tertiary education.

\section{Results}

Factor analysis (PCA) was applied to the full set of eight statistical indicators and separately to the two subsets depicting secondary and tertiary education. The rotated results of PCA analysis (Table 1) confirm that the stratification of the secondary education system (indicated by the number of school types or distinct educational programmes) is strongly correlated with its vocational specificity (indicated by the proportion of fifteen-year-olds enrolled in programmes that give access to vocational studies, or direct access to the labour market and upper secondary education enrolment in general education programmes). Another welldefined dimension of a country's education system comprises enrolment rates, expenditure on tertiary education, financial aid to students, and the system's openness to private resources (indicating a demand driven system). Although the correlation of the two dimensions (SCND, TERT) is very high and significant $(\mathrm{r}=0.627, \mathrm{p}<0.001)$, and the analysis of the full set suggests that there is clearly one strong dimension that consistently describes a country's education system as a whole (component DIM1 in Table 1), for descriptive and analytical purposes we decided to keep the two dimensions separate (SCND, TERT). For the sake of simplicity we refer to them as the 'openness of secondary education' and the 'openness of tertiary education'.

Since the OECD statistical data used to describe the openness and permeability of education systems contains missing values, and since dropping the countries with the missing data from the analyses would have reduced the number of units for multilevel analysis below a critical level, we used the regression method of imputation for the missing data. ${ }^{14}$ Since the correlation between TERT and

${ }^{14}$ SPSS Missing Value Analysis was applied (a regression method augmenting estimates with random components). For details see: http://www.siue.edu/IUR/SPSS/SPSS\%20M issing\%20Value\%20Analysis\%207.5.pdf. 
P. Matějü, M. L. Smith, P. Soukup, J. Basl: Determination of College Expectations in OECD Countries

Table 1. Factor analysis (PCA) of the openness of secondary and tertiary education

\begin{tabular}{lcccc}
\hline & \multicolumn{2}{c}{ Before rotation } & \multicolumn{2}{c}{ After rotation } \\
Variable & DIM1 & DIM2 & SCDN & TERT \\
\hline GENSEC & 0.638 & 0.455 & 0.650 & - \\
NUMPRG & -0.922 & 0.177 & -0.853 & - \\
VOCAT & -0.520 & 0.486 & -0.702 & - \\
EXPSEC & 0.668 & -0.310 & 0.705 & - \\
ENROL & 0.721 & -0.031 & - & 0.720 \\
PRVRSC & 0.339 & 0.882 & - & 0.615 \\
FINAID & 0.681 & -0.238 & - & 0.618 \\
EXPTER & 0.741 & 0.294 & - & 0.793 \\
\% of VAR & 45.3 & 18.6 & 53.5 & 47.7 \\
\hline
\end{tabular}

Figure 1. Openness of the secondary and tertiary education systems in OECD countries (dimensions SCND and TERT)




Figure 2. College expectations by measured ability (quintiles) and parental SES (quintiles)
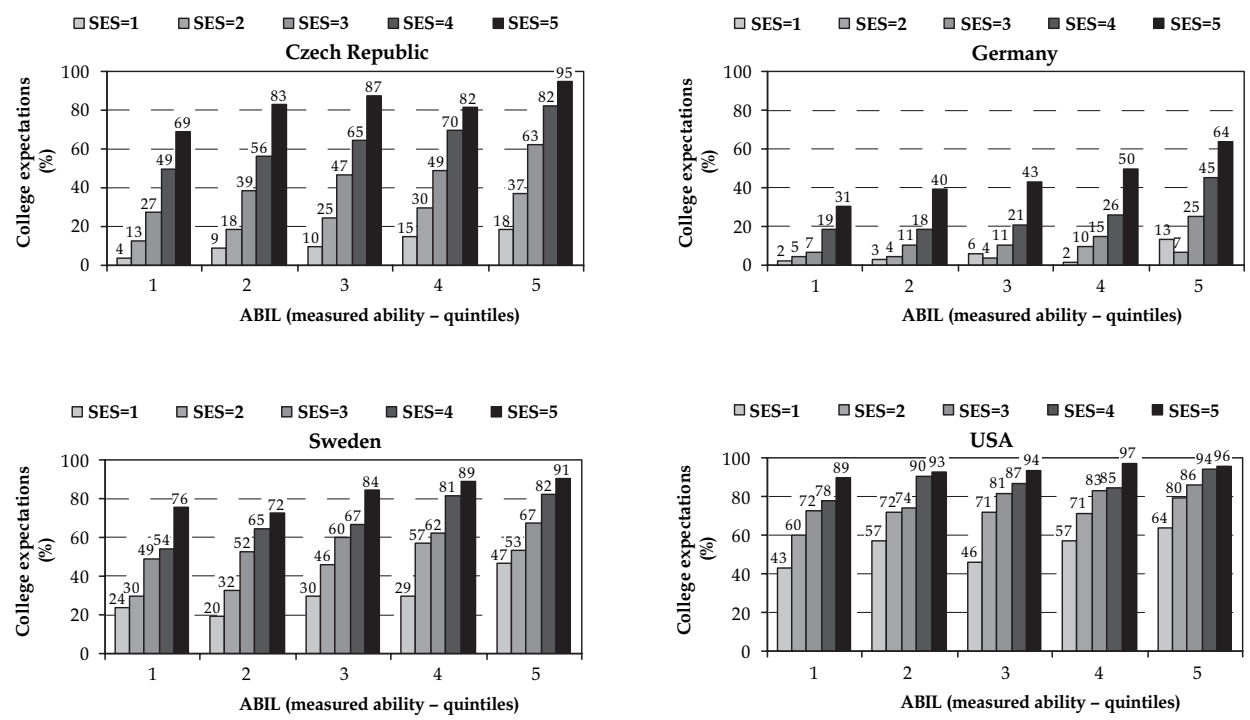

SCND was not affected by the imputation, we decided to use imputed data for further analysis.

The values of the two dimensions (principal components) in OECD/PISA countries $^{15}$ are displayed in Figure 1. At first glance, a large number of European countries (e.g. the Czech Republic, the Netherlands, Austria, Slovakia, Germany, Italy, Ireland, France, Belgium, etc.) show low levels of openness in both the secondary and tertiary systems of education. The United States, Canada, New Zealand, and Australia, on the one hand, and Sweden, Norway Denmark, and Finland, on the other, show consistently greater openness in both segments of the education system.

The results of a simple descriptive analysis of the effects of ability and parental socio-economic status in three selected countries exhibiting different levels of education system stratification (the Czech Republic, Germany, the United States and Sweden), displayed in Figure 2, reveal the different effects of socioeconomic background in these three countries. In the Czech Republic, a country with one of the most stratified systems of secondary education and one of the least accessible systems of tertiary education in the OECD, only $18 \%$ of the most competent fifteen-year-olds from the lowest SES group (SES =1) expect to achieve

${ }^{15}$ Hereinafter, 'OECD/PISA countries' refers to the OECD countries that participated in the PISA 2003 project. 
Figure 3. Logistic regression coefficients (B) of aspiration on ability (ABIL) and socio-economic status of parents (HISEI), controlling for gender. Variables ABIL and HISEI have been standardised

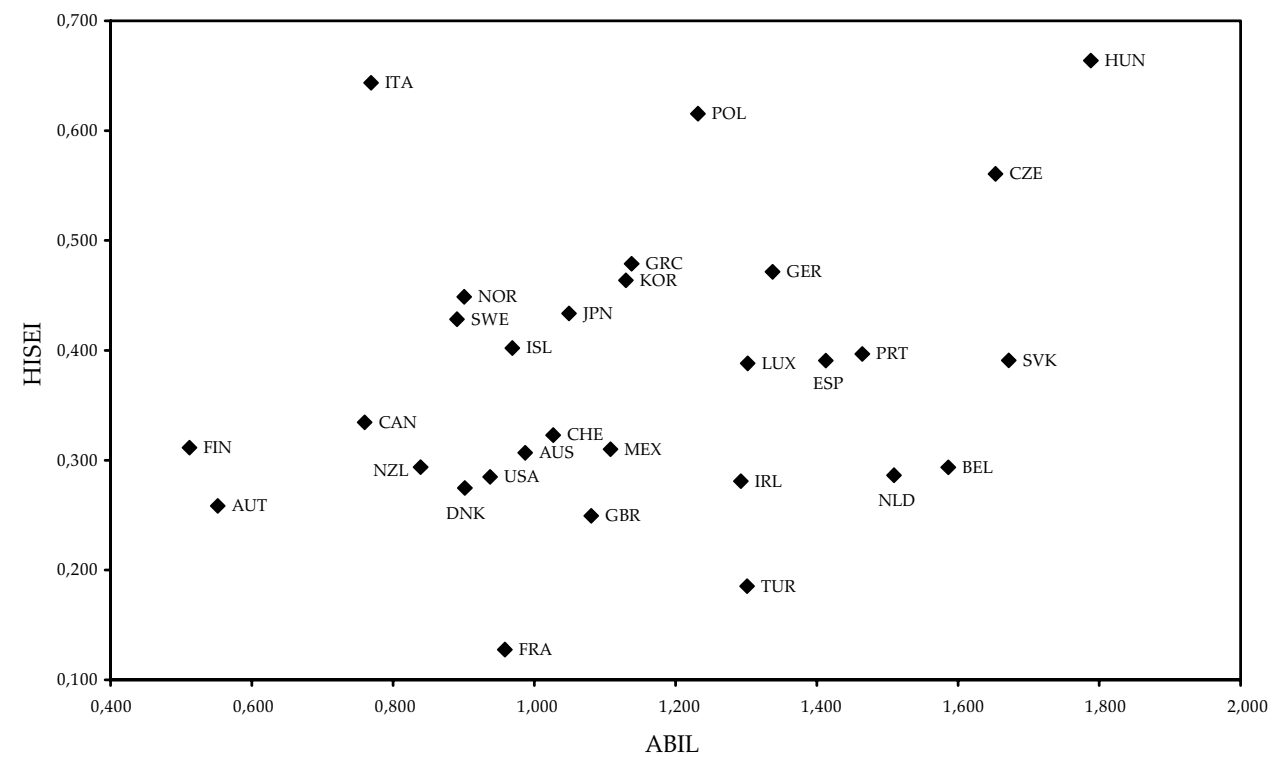

an education at the tertiary level, while in the highest SES group the figure is $95 \%$ (ratio 0.18). In the United States and Sweden - the countries with the least stratified secondary education and the most open tertiary education - highly capable adolescents from lower strata are much more likely to expect to continue on to college than their Czech counterparts (18\% in the Czech Republic, compared to $64 \%$ in the US and $47 \%$ in Sweden). Thus, the contrast between the lowest and highest SES quintiles is much smaller in those countries (US: 64/96, ratio 0.66, Sweden $47 / 91$, ratio 0.51 ).

The logistic regression of college expectations on ability (ABIL), parental socio-economic status (HISEI), and gender (SEX), ${ }^{16}$ which was applied to assess the net effect of ability and parental socio-economic status on college expectations and the degree to which college expectations are determined by ability, gender, and parental socio-economic status, revealed significant differences between countries, especially in the net effect of socio-economic background. Figure 3 displays the standardised logistic regression coefficients (B) of expectations on ability (ABIL) and the socio-economic status of parents (HISEI), controlling for gender. Consistent with the results of the descriptive analysis and with hypo-

${ }^{16}$ The SPSS binomial logistic regression procedure was applied. See the SPSS command file in the Appendix. 
Figure 4. Standardised values (Z-scores) of the model coefficient of determination (Nagelkerke's $\mathrm{R}^{2}$ ) from the logistic regression of college expectations on ability, gender, and parental socio-economic status



theses H1, the net effect of socio-economic status is much stronger in the Czech Republic, Germany, Hungary, Poland, and other Central European countries than in the US, Canada, Australia, France, and other countries with less stratified and more open education systems.

The overall degree to which college expectations are determined by ability, gender, and parental socio-economic status was assessed by the model coefficient of determination (Nagelkerke's $\left.\mathrm{R}^{2}\right) .{ }^{17}$ The values of the coefficient range from more than 0.40 (Hungary, the Czech Republic, Slovakia, Portugal, Belgium, the Netherlands, Poland, and Spain) to less than 0.25 (Denmark, New Zealand, France, the United States, Korea, Canada, Australia, and Finland).

To simplify the graphic presentation, we transformed the Nagelkerke's $\mathrm{R}^{2}$ values to their z-scores (see Figure 4 for the results) and also conducted secondlevel principal component analysis, which identified a single dimension representing the openness and permeability of the education system on the whole

${ }^{17}$ Nagelkerke's R-Square is a modification of the Cox and Snell coefficient of determination. It divides Cox and Snell's $\mathrm{R}^{2}$ by its maximum in order to attain a measure that ranges from 0 to 1 . Therefore, Nagelkerke's $R^{2}$ will normally be higher than the Cox and Snell measure but will tend to run lower than the corresponding OLS R ${ }^{2}$. Nagelkerke's $R^{2}$ is the most-reported of the R-squared estimates [see Nagelkerke 1991]. 
Figure 5. The relationship between the determination of college expectations (ZDETEXP) and the composite variable indicating openness and permeability of the education system (OPENNESS)

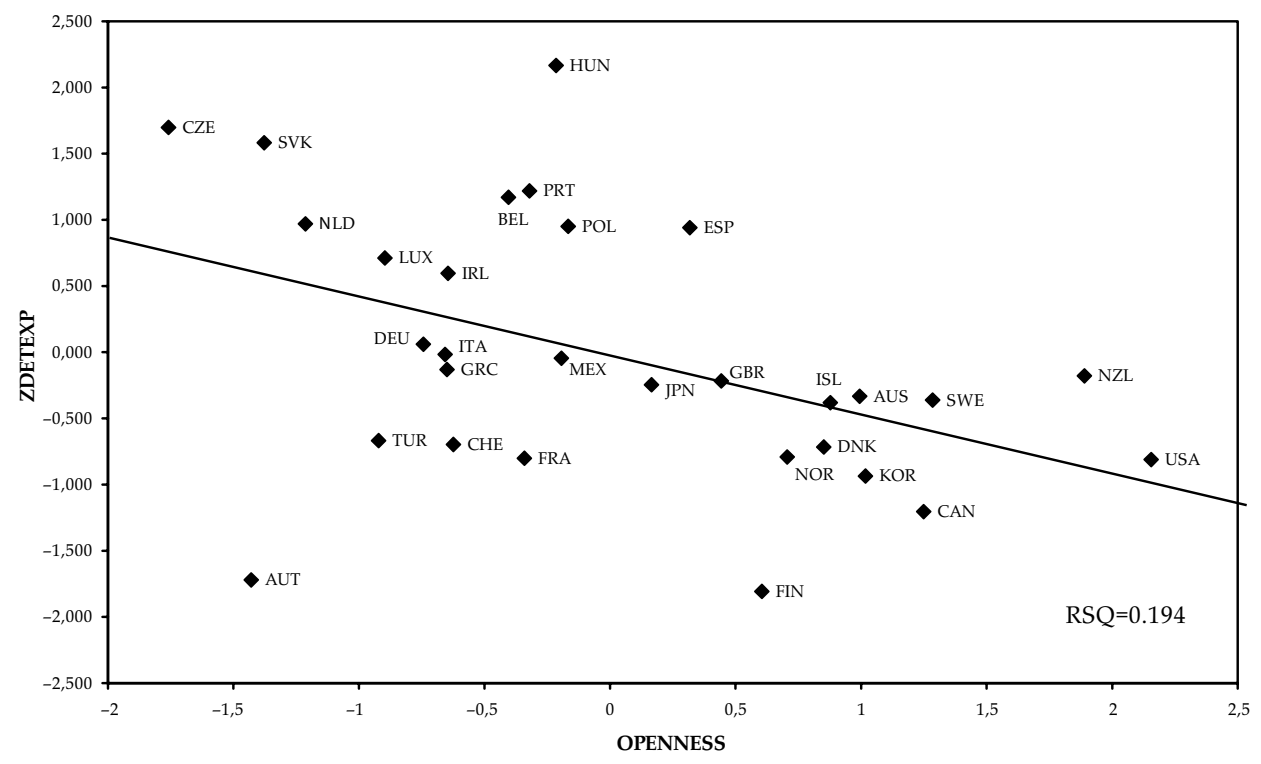

(variable OPENNESS). ${ }^{18}$ As the first hypothesis (H1) predicted, we found a strong relationship between the determination of college expectations at the individual level (ZDETEXP) on the one hand, and the openness and permeability of the education system (OPENNESS) on the other. ${ }^{19}$

Figure 5 displays individual OECD/PISA countries in a two-dimensional space defined by the determination of college expectations (ZDETEXP) and the overall openness and permeability of the education system (OPENNESS). The figure confirms the strong relationship between the openness and permeability of the education system, assessed at the country level, and the degree of overall determination of college expectations, assessed at the individual level.

In order to test the specific effects of the relevant characteristics of education systems on the determination of college expectations, ${ }^{20}$ we ran a series of regres-

${ }^{18}$ One identified component, OPENNESS, accounted for $81 \%$ of the variance with loadings 0.902 for both SCND and TERT.

${ }_{19}$ The regression coefficients of DETASP on SCDN, TERT and OPENNESS (b/se/sig) are: SCND (-.452/0.188/0.023), TERT (-.375/0.172/0.038), OPENNESS $(-.441 / 0.170 / 0.015)$

${ }^{20}$ There were three dependent variables: the overall determination of college aspirations by ability, socio-economic background and gender (ZDETEXP), the effect of ability on aspirations (RCABIL), and the effect of socio-economic background on aspirations (RCHISEI). 
Table 2. Regression analysis of the overall determination of college aspirations (ZDETEXP)*, the effect of ability on college expectations (RCABIL), and the effect of socio-economic background at the country level

\begin{tabular}{|c|c|c|c|c|c|c|c|}
\hline \multirow{2}{*}{\multicolumn{2}{|c|}{ Model }} & \multicolumn{2}{|c|}{$\begin{array}{l}\text { Unstandardised } \\
\text { coefficients }\end{array}$} & \multirow{2}{*}{$\begin{array}{c}\text { Standardised } \\
\text { coefficients } \\
\text { Beta }\end{array}$} & \multirow[t]{2}{*}{$\mathrm{t}$} & \multirow[t]{2}{*}{ Sig. } & \multirow[t]{2}{*}{$\mathrm{R}^{2}$} \\
\hline & & $\mathrm{B}$ & Std. Error & & & & \\
\hline \multicolumn{8}{|c|}{ Dependent variable $=$ ZDETEXP } \\
\hline \multirow[t]{2}{*}{1} & (Constant) & .009 & .169 & & .055 & .957 & \multirow{2}{*}{.172} \\
\hline & SCND & -.452 & .188 & -.415 & -2.411 & .023 & \\
\hline \multirow[t]{2}{*}{2} & (Constant) & -.024 & .172 & & -.141 & .889 & \multirow{2}{*}{.145} \\
\hline & TERT & -.375 & .172 & -.380 & -2.176 & .038 & \\
\hline \multirow[t]{3}{*}{3} & (Constant) & -.006 & .171 & & -.036 & .971 & \multirow{3}{*}{.196} \\
\hline & SCND & -.316 & .242 & -.290 & -1.310 & .201 & \\
\hline & TERT & -.196 & .219 & -.198 & -.896 & .378 & \\
\hline \multicolumn{8}{|c|}{ Dependent variable $=$ RCABIL } \\
\hline \multirow[t]{2}{*}{1} & (Constant) & 1.097 & .058 & & 18.997 & .000 & \multirow{2}{*}{.309} \\
\hline & SCND & -.226 & .064 & -.556 & -3.537 & .001 & \\
\hline \multirow[t]{2}{*}{2} & (Constant) & 1.085 & .066 & & 16.404 & .000 & \multirow{2}{*}{.096} \\
\hline & TERT & -.114 & .066 & -.311 & -1.729 & .095 & \\
\hline \multirow[t]{3}{*}{3} & (Constant) & 1.099 & .059 & & 18.622 & .000 & \multirow{3}{*}{.311} \\
\hline & SCND & -.242 & .084 & -.595 & -2.901 & .007 & \\
\hline & TERT & .023 & .076 & .062 & .304 & .764 & \\
\hline \multicolumn{8}{|c|}{ Dependent variable $=$ RCHISEI } \\
\hline \multirow[t]{2}{*}{1} & (Constant) & .338 & .026 & & 12.774 & .000 & \multirow{2}{*}{.100} \\
\hline & SCND & -.052 & .029 & -.316 & -1.760 & .089 & \\
\hline \multirow[t]{2}{*}{2} & (Constant) & .336 & .028 & & 12.093 & .000 & \multirow{2}{*}{.011} \\
\hline & TERT & -.016 & .028 & -.106 & -.566 & .576 & \\
\hline \multirow[t]{3}{*}{3} & (Constant) & .339 & .027 & & 12.642 & .000 & \multirow{3}{*}{.113} \\
\hline & SCND & -.067 & .038 & -.410 & -1.763 & .089 & \\
\hline & TERT & .022 & .034 & .151 & .648 & .522 & \\
\hline
\end{tabular}

* The dependent variable ZDETEXP has been defined as the z-score of the coefficient of determination of college expectations (Nagelkerke's $\mathrm{R}^{2}$ ) from the model with three independent variables: ability, gender, and parental socio-economic status. 
sion analyses at the country level. The results from this exercise are displayed in Tables 2 to 5 . We started with a simple model containing only two independent variables: SCND and TERT (Table 2). As for the degree of overall determination of expectations, both of these independent variables show a strong and significant effect $(-.415,-.380) .{ }^{21}$ Therefore, the assumption was confirmed that greater openness of secondary and tertiary education is associated with a weaker overall determination of expectations. The degree to which expectations are determined by ability (RCABIL) also strongly depends on the openness of secondary and tertiary education $(-.556,-.311)$. The degree of determination of expectations by socio-economic background shows a much higher sensitivity to the openness of the secondary education system than the tertiary system.

Table 3 shows the results of regressions for the overall determination of expectations in which the composite variable 'openness of tertiary education' was broken down into the three most relevant original indicators (ENROL, PRVRSC, and FINAID); also, the between-school variance (ICC) was added to the set of independent variables. The story becomes more interesting, particularly because the between-school variance in expectations turned out to be by far the strongest predictor of their overall determination. It should be noted that this is the only variable in the whole model that remains strong and significant when it comes to net effects (before ICC was added to the model, it was the composite variable SCND, i.e. the 'openness of secondary education'). The results show that the larger the differences in college expectations at the school level (ICC), the stronger the effects of both students' socio-economic background and ability.

Importantly, when either the openness of the secondary education or between-school variance in expectations enter the model, the effects of enrolment in tertiary education and indicators of its financing (traditionally thought to be important in shaping college expectations) become negligible. The same story emerges from Table 4, which displays the results for the degree of determination of expectations (RCABIL) by ability. Again, the openness of secondary education and the between-school variance in expectations override the effects of all relevant characteristics of tertiary education, including the enrolment rate (ENROL) and its model of financing (PRVSRC, FINAID).

As for the regression analysis of the effect of family socio-economic status on college expectations (RCHISEI), the results presented in Table 5 are quite similar to those presented so far, with the only difference consisting in the fact

\footnotetext{
${ }^{21}$ Since the analysis was performed on all the PISA 2003 countries, i.e. we in fact worked with a full set of cases, and thus it does not make much sense to use statistical significance stricto sensu, we refer to it just to avoid over-interpreting the coefficients themselves, as they were produced on a very small sample of just thirty countries. On the other hand, we may assume that the thirty countries in the analysis are a sample of the larger 'population' of developed and developing countries (which may include about sixty countries), to which the results can be generalised. In this case we would use the significance level of 0.1 instead of 0.05 .
} 
Table 3. Regression analysis of the overall determination of college expectations (ZDETEXP)* at the country level

\begin{tabular}{|c|c|c|c|c|c|c|c|}
\hline \multicolumn{2}{|c|}{ Model } & \multicolumn{2}{|c|}{$\begin{array}{l}\text { Unstandardised } \\
\text { coefficients }\end{array}$} & \multirow{2}{*}{$\begin{array}{c}\text { Standardised } \\
\text { coefficients } \\
\text { Beta }\end{array}$} & \multirow[t]{2}{*}{$\mathrm{t}$} & \multirow[t]{2}{*}{ Sig. } & \multirow[t]{2}{*}{$\mathrm{R}^{2}$} \\
\hline & & B & Std. Error & & & & \\
\hline \multirow[t]{2}{*}{1} & (Constant) & .009 & .169 & & .055 & .957 & \multirow{2}{*}{.172} \\
\hline & SCND & -.452 & .188 & -.415 & -2.411 & .023 & \\
\hline \multirow[t]{2}{*}{2} & (Constant) & -1.025 & .301 & & -3.400 & .002 & \multirow{2}{*}{.354} \\
\hline & ICC & 4.534 & 1.159 & .595 & 3.914 & .001 & \\
\hline \multirow[t]{2}{*}{3} & (Constant) & .646 & .909 & & .711 & .484 & \multirow{2}{*}{.023} \\
\hline & ENROL & -.011 & .014 & -.152 & -.755 & .458 & \\
\hline \multirow[t]{2}{*}{4} & (Constant) & .085 & .283 & & .299 & .767 & \multirow{2}{*}{.010} \\
\hline & PRVRSC & -.005 & .010 & -.099 & -.519 & .608 & \\
\hline \multirow[t]{2}{*}{5} & (Constant) & .290 & .343 & & .847 & .405 & \multirow{2}{*}{.042} \\
\hline & FINAID & -.018 & .017 & -.206 & -1.094 & .284 & \\
\hline \multirow[t]{5}{*}{6} & (Constant) & -.560 & 1.078 & & -.520 & .609 & \multirow{5}{*}{.188} \\
\hline & SCND & -.526 & .268 & -.500 & -1.964 & .063 & \\
\hline & ENROL & .007 & .017 & .106 & .436 & .668 & \\
\hline & PRVRSC & .001 & .010 & .013 & .065 & .949 & \\
\hline & FINAID & .003 & .020 & .037 & .161 & .873 & \\
\hline \multirow[t]{6}{*}{7} & (Constant) & -1.372 & .968 & & -1.417 & .172 & \multirow{6}{*}{.428} \\
\hline & SCND & .129 & .323 & .122 & .399 & .694 & \\
\hline & ICC & 5.568 & 1.922 & .737 & 2.897 & .009 & \\
\hline & ENROL & .007 & .014 & .095 & .456 & .653 & \\
\hline & PRVRSC & -.005 & .009 & -.094 & -.523 & .606 & \\
\hline & FINAID & -.010 & .018 & -.118 & -.578 & .569 & \\
\hline
\end{tabular}

* The dependent variable ZDETEXP has been defined as the $\mathrm{z}$-score of the coefficient of determination of college expectations (Nagelkerke's $\mathrm{R}^{2}$ ) from the model with three independent variables: ability, gender, and parental socio-economic status. 
Table 4. Regression analysis of the effect of ability on college expectations (RCABIL) * at the country level

\begin{tabular}{|c|c|c|c|c|c|c|c|}
\hline \multirow[t]{2}{*}{ Model } & & \multicolumn{2}{|c|}{$\begin{array}{l}\text { Unstandardised } \\
\text { coefficients }\end{array}$} & \multirow{2}{*}{$\begin{array}{c}\text { Standardised } \\
\text { coefficients } \\
\text { Beta }\end{array}$} & \multirow[t]{2}{*}{$t$} & \multirow[t]{2}{*}{ Sig. } & \multirow[t]{2}{*}{$\mathrm{R}^{2}$} \\
\hline & & B & Std. Error & & & & \\
\hline \multirow[t]{2}{*}{1} & (Constant) & 1.097 & .058 & & 18.997 & .000 & \multirow{2}{*}{.309} \\
\hline & SCND & -.226 & .064 & -.556 & -3.537 & .001 & \\
\hline \multirow[t]{2}{*}{2} & (Constant) & .700 & .111 & & 6.299 & .000 & \multirow{2}{*}{.371} \\
\hline & ICC & 1.735 & .427 & .609 & 4.061 & .000 & \\
\hline \multirow[t]{2}{*}{3} & (Constant) & 1.573 & .338 & & 4.649 & .000 & \multirow{2}{*}{.085} \\
\hline & ENROL & -.008 & .005 & -.291 & -1.490 & .149 & \\
\hline \multirow[t]{2}{*}{4} & (Constant) & 1.071 & .107 & & 10.033 & .000 & \multirow{2}{*}{.001} \\
\hline & PRVRSC & .001 & .004 & .035 & .182 & .857 & \\
\hline \multirow[t]{2}{*}{5} & (Constant) & 1.245 & .126 & & 9.870 & .000 & \multirow{2}{*}{.078} \\
\hline & FINAID & -.009 & .006 & -.280 & -1.515 & .141 & \\
\hline \multirow[t]{5}{*}{6} & (Constant) & 1.009 & .368 & & 2.743 & .012 & \multirow{5}{*}{.359} \\
\hline & SCND & -.246 & .092 & -.608 & -2.689 & .014 & \\
\hline & ENROL & -.001 & .006 & -.027 & -.126 & .901 & \\
\hline & PRVRSC & .004 & .003 & .202 & 1.113 & .278 & \\
\hline & FINAID & .002 & .007 & .051 & .251 & .804 & \\
\hline \multirow[t]{6}{*}{7} & (Constant) & .824 & .367 & & 2.245 & .036 & \multirow{6}{*}{.444} \\
\hline & SCND & -.097 & .122 & -.239 & -.791 & .438 & \\
\hline & ICC & 1.268 & .729 & .436 & 1.740 & .097 & \\
\hline & ENROL & -.001 & .005 & -.034 & -.163 & .872 & \\
\hline & PRVRSC & .003 & .003 & .138 & .782 & .443 & \\
\hline & FINAID & -.001 & .007 & -.041 & -.202 & .842 & \\
\hline
\end{tabular}

* The dependent variable RCABIL has been defined as the standardised regression coefficient for ability (ABIL) in the model with three independent variables: ability, gender, and parental socio-economic status. 
Table 5. Regression analysis of the effect of family socio-economic status on college expectations (RCHISEI) ${ }^{*}$ at the country level

\begin{tabular}{|c|c|c|c|c|c|c|c|}
\hline \multirow[t]{2}{*}{ Model } & & \multicolumn{2}{|c|}{$\begin{array}{l}\text { Unstandardised } \\
\text { coefficients }\end{array}$} & \multirow{2}{*}{$\begin{array}{c}\text { Standardised } \\
\text { coefficients } \\
\text { Beta }\end{array}$} & \multirow[t]{2}{*}{$\mathrm{T}$} & \multirow[t]{2}{*}{ Sig. } & \multirow[t]{2}{*}{$\mathrm{R}^{2}$} \\
\hline & & B & Std. Error & & & & \\
\hline \multirow[t]{2}{*}{1} & (Constant) & .338 & .026 & & 12.774 & .000 & \multirow{2}{*}{.172} \\
\hline & SCND & -.052 & .029 & -.316 & -1.760 & .089 & \\
\hline \multirow[t]{2}{*}{2} & (Constant) & .208 & .049 & & 4.269 & .000 & \multirow{2}{*}{.354} \\
\hline & ICC & .568 & .187 & .497 & 3.031 & .005 & \\
\hline \multirow[t]{2}{*}{3} & (Constant) & .355 & .145 & & 2.448 & .022 & \multirow{2}{*}{.023} \\
\hline & ENROL & .000 & .002 & -.035 & -.172 & .865 & \\
\hline \multirow[t]{2}{*}{4} & (Constant) & .301 & .042 & & 7.145 & .000 & \multirow{2}{*}{.010} \\
\hline & PRVRSC & .002 & .001 & .208 & 1.104 & .279 & \\
\hline \multirow[t]{2}{*}{5} & (Constant) & .401 & .051 & & 7.905 & .000 & \multirow{2}{*}{.042} \\
\hline & FINAID & -.004 & .002 & -.286 & -1.550 & .133 & \\
\hline \multirow[t]{5}{*}{6} & (Constant) & .220 & .167 & & 1.317 & .202 & \multirow{5}{*}{.188} \\
\hline & SCND & -.059 & .041 & -.357 & -1.430 & .168 & \\
\hline & ENROL & .002 & .003 & .144 & .606 & .551 & \\
\hline & PRVRSC & .002 & .002 & .287 & 1.436 & .166 & \\
\hline & FINAID & -.002 & .003 & -.156 & -.698 & .493 & \\
\hline \multirow[t]{6}{*}{7} & (Constant) & .126 & .163 & & .771 & .450 & \multirow{6}{*}{.428} \\
\hline & SCND & .017 & .054 & .100 & .305 & .764 & \\
\hline & ICC & .644 & .324 & .540 & 1.991 & .060 & \\
\hline & ENROL & .001 & .002 & .136 & .612 & .547 & \\
\hline & PRVRSC & .002 & .001 & .208 & 1.091 & .288 & \\
\hline & FINAID & -.004 & .003 & -.270 & -1.242 & .229 & \\
\hline
\end{tabular}

* The dependent variable RCHISEI has been defined as the standardised regression coefficient for family socio-economic status (HISEI) in the model with three independent variables: ability, gender, and parental socio-economic status. 
that the between-school variance is the only independent variable in the model showing a strong and significant effect. As for the role of tuition fees (PRVSRC) and financial aid to students, it is interesting to see that in the final model (Table 5, model 7) their effects go in the direction one would expect: the presence of tuition fees (PRVRSC) increases the role of socio-economic background in the formation of expectations (.208), while the presence of financial aid to students tends to eliminate it (-.270). However, these effects are not statistically significant, and also, as already noted, largely overridden by the effects of secondary school system stratification. Given these results, we find strong support for hypothesis $\mathrm{H} 2$ (as well as its specifications: $\mathrm{H} 2 \mathrm{a}$ and $\mathrm{H} 2 \mathrm{~b}$ ).

\section{Conclusion}

The analysis of the OECD data confirmed the hypothesis that the degree of stratification in the secondary education system, together with its vocational specificity, constitutes one dimension indicative of the permeability of the secondary education system (assumption A1). We also found that there is a strong association between the permeability of secondary education and the openness of tertiary education (assumption A2). These two intertwined characteristics of an education system strongly predict the degree to which college expectations are determined by socio-economic background, ability, and gender (H1).

The series of regression analyses carried out on the country level produced strong evidence supporting the hypothesis that the most important characteristics of an education system that generate a strong degree of determination of college expectations by ability and socio-economic background pertain primarily to secondary, not tertiary, education. In this regard, the decisive aspects of secondary education are the degree of secondary school system stratification and vocational specificity on the one hand, and between-school variance in college expectations (measured by the intra-class correlation) on the other. At the country level, these characteristics of the secondary school system largely override the effects of the characteristics of tertiary education, such as the role of tuition fees and financial aid to students. It should be emphasised that the results of our analysis and our main conclusions are not at odds with research that has shown that, at the individual level, the actual and perceived levels of tuition fees, student financial aid, and the factual and perceived 'openness' or 'closedness' of the tertiary education system, actually may matter a great deal. These questions will be on the agenda of our longitudinal research we launched in 2003 (PISA-L, fifteen-year-olds) and 2004 (first-year university students).

As for the main message of our analysis for educational policy, we believe that we have gone a step further in assessing the role of the institutional structures of education systems and the degree of their openness and permeability in the formation of college expectations of pupils. Our analysis strongly supports 
the idea that in order to increase equity in access to higher education, policymakers should focus primarily on the secondary school system, particularly on the existing structural conditions for the reproduction of inequality in access to higher education through secondary school system stratification and other sources of differences between schools.

JOSEF BASL is a doctoral student and research fellow at the Department of Sociology of Education and Stratification at the Institute of Sociology of the Academy of Sciences of the Czech Republic. His major research interests are inequality in education and educational policy.

Petr MATĚJU is a professor of sociology and chair of the Department of Sociology of Education and Stratification at the Institute of Sociology of the Academy of Sciences of the Czech Republic. His major research interests are social stratification and mobility, and inequality and equity in education. He has published a number of articles on social transformation in East Central Europe and co-edited three books: Ten Years of Rebuilding Capitalism, Czech Society after 1989 (published in 1998 in English), Inequality - Justice - Politics (in Czech, published in 2000), and Unequal Chances in Education (in Czech, published in 2006).

Michael L. SMith is a research fellow at the Department of Sociology of Education and Stratification at the Institute of Sociology of the Academy of Sciences of the Czech Republic. He is also a doctoral candidate in political science at the New School for Social Research in New York. He has broad research interests in both political science (democratic governance, voter behaviour) and sociology (social policy, social inequality).

PETR SOUKUP is a research fellow at the Department of Sociology of Education and Stratification at the Institute of Sociology of the Academy of Sciences of the Czech Republic. He is also a teaching assistant at the Faculty of Social Sciences of Charles University. He specialises in the teaching and applications of statistical methodology and especially multivariate statistical methods and multilevel analysis.

\section{References}

Alexander, Karl L. and Bruce K. Eckland. 1975. 'Contextual Effects in the High School Attainment Process.' American Sociological Review 40: 402-16.

Blau, Peter M. and Otis D. Duncan. 1967. The American Occupational Structure. New York: Wiley.

Buchmann, Claudia and Ben Dalton. 2002. 'Interpersonal Influences and Educational Expectations in 12 Countries: The Importance of Institutional Context.' Sociology of Education 75: 99-122.

Duncan, Otis D. 1968. 'Ability and Achievement.' Eugenics Quarterly 15: 1-11. 
Ganzeboom, Harry B. G., Paul M. de Graaf and Donald J. Treiman, with Jan de Leeuw. 1992. 'A Standard International Socioeconomic Index of Occupational Status.' Social Science Research 21: 1-56.

Haller, Archibald. O. and Alejandro Portes. 1973. 'Status Attainment Processes.' Sociology of Education 46 (1): 51-91.

Han, Wan S. 1968. 'Discrepancy in Socio-economic Level of Aspirations and Perception of Illegitimate Expediency.' American Journal of Sociology 74: 240-7.

Han, Wan S. 1969. 'Two Conflicting Themes: Common Values versus Class Differential Values.' American Sociological Review 34: 679-90.

Hauser, Robert M. 1972. 'Disaggregating a Social-Psychological Model of Educational Attainment.' Social Science Research 11: 59-188.

Hauser, Robert M., Shu-Ling Tsai and William H. Sewell. 1983. 'A Model of Stratification with Response Error in Social and Psychological Variables.' Sociology of Education 56: $20-46$.

Herriott, Robert E. 1963. 'Some Determinants of Educational Aspirations.' Harvard Educational Review 33: 157-177.

Hyman, Herbert H. 1953. 'The Value Systems of Different Classes: A Social Psychological Contribution to the Analysis of Stratification.' Pp. 426-442 in Class, Status and Power: A Reader in Social Stratification, edited by R. Bendix and S. M. Lipset. Glencoe: Free Press.

Jencks, Christopher. 1972. Inequality: A Reassessment of the Effect of Family and Schooling in America. New York: Basic Books.

Kahl, Joseph A. 1953. ‘Educational and Occupational Aspirations of "Common Man" Boys.' Harvard Educational Review 23: 186-203.

Karabel, Jerome and Alexander W. Astin. 1975. 'Social Class, Academic Ability, and College "Quality".' Social Forces 53: 381-398.

Kerckhoff, Alan C. 1976. 'The Status Attainment Process: Socialization or Allocation?' Social Forces 55: 368-381.

Kerckhoff, Alan C. 1977. 'The Realism of Educational Ambitions in England and the United States.' American Sociological Review 42: 563-571.

Kerckhoff, Alan C. 2001. 'Education and Social Stratification Processes in Comparative Perspective.' Sociology of Education Extra Issue: 3-18.

Kerckhoff, Alan C. and Richard T. Campbell. 1977a. 'Black-White Differences in the Educational Attainment Process.' Sociology of Education 50: 15-27.

Kerckhoff, Alan C. and Richard T. Campbell. 1977b. 'Race and Social Status Differences in the Explanation of Educational Ambition.' Social Forces 55: 701-714.

Müller, Walter and Yossi Shavit. 1998. 'The Institutional Embeddedness of the Stratification Process: A Comparative Study of Qualifications and Occupations in Thirteen Countries.' Pp. 1-48 in From School to Work: A Comparative Study of Educational Qualifications and Occupational Destinations, edited by Y. Shavit and W. Muller. Oxford: Oxford University Press.

Nagelkerke, N. J. D. 1991. 'A Note on a General Definition of the Coefficient of Determination.' Biometrika 78: 691-692.

OECD. 2005a. PISA 2003 Data Analysis Manual. Paris: OECD (available at https://www.oecd.org/dataoecd/35/32/35002862.pdf).

OECD. 2005b. PISA 2003 Technical Manual. Paris: OECD.

OECD. 2005c. School Factors Related to Quality and Equity. Results from PISA 2000. Paris: OECD.

OECD. 2003. Education at a Glance 2003. Paris: OECD.

OECD. 2004. Education at a Glance 2004. Paris: OECD.

OECD. 2005d. Education at a Glance 2005. Paris: OECD. 
OECD. 2006. Education at a Glance 2006. Paris: OECD.

Reissman, Leonard. 1953. 'Levels of Aspiration and Social Class.' American Sociological Review 18: 233-242.

Sewell, William H. 1961. 'Social Class and Childhood Personality.' Sociometry 24: 340-356.

Sewell, William H. 1963. 'Some Recent Developments in Socialization Theory and Research.' The Annals of the American Academy of Political and Social Science 349: 163-181.

Sewell, William H. and Robert M. Hauser. 1972. 'Causes and Consequences of Higher Education: Models of the Status Attainment Process.' American Journal of Agricultural Economics 54: 851-861.

Sewell, William H. and Robert M. Hauser. 1975. Education, Occupation and Earnings. New York: Academic Press.

Sewell, William H. and Vimal P. Shah. 1967. 'Socioeconomic Status, Intelligence, and the Attainment of Higher Education.' Sociology of Education 40: 1-23.

Sewell, William H. and Vimal P. Shah. 1968a. 'Social Class, Parental Encouragement, and Educational Aspirations.' American Journal of Sociology 73: 559-572.

Sewell, William H. and Vimal P. Shah. 1968b. 'Parents' Education and Children's Educational Aspirations and Achievements.' American Sociological Review 33: 191-209.

Sewell, William H., Archibald O. Haller and Murray A. Straus. 1957 'Social Status and Educational and Occupational Aspirations.' American Sociological Review 22: 67-73.

Sewell, William H., Archibald O. Haller and Alejandro Portes. 1969. 'The Educational and Early Occupational Attainment Process.' American Sociological Review 34: 82-92.

Sewell, William H., Archibald O. Haller and George W. Ohlendorf. 1970. 'The Educational and Early Occupational Status Attainment Process: Replication and Revision.' American Sociological Review 35: 1014-1027.

Simmons, Roberta G. and Morris Rosenberg. 1971. 'Functions of Children's Perceptions of the Stratification System.' American Sociological Review 36: 235-49.

Snijders, Tom A. B. and Roel J. Bosker. 1999. Multilevel Analysis: An Introduction to Basic and Advanced Multilevel Modeling. London: Sage Publisher.

Turner, Ralph H. 1960. 'Sponsored and Contest Mobility and the School System.' American Sociological Review 25: 855-867.

TIMSS (Third International Mathematics and Science Study). 1995. IEA. Retrieved http://www.iea.nl/timss1995.html.

Williams, Trevor H. 1972. 'Educational Aspirations: Longitudinal Evidence in Their Development in Canadian Youth.' Sociology of Education 45: 107-133.

Wilson, Kenneth L. and Alejandro Portes. 1975. 'The Educational Attainment Process: Results from a National Sample.' American Journal of Sociology 81: 343-63. 


\section{Appendix}

Table A1. Statistical indicators used in the analysis of education systems

\begin{tabular}{|c|c|c|}
\hline Acronym & Description & Source \\
\hline GENSEC & $\begin{array}{l}\text { Upper secondary education enrolment in general education } \\
\text { programs (2003) }\end{array}$ & $\mathrm{EaG}, \mathrm{C} 2.1$ \\
\hline NUMPRG & $\begin{array}{l}\text { Number of school types or distinct educational programmes } \\
\text { available to fifteen-year-olds (2003) }\end{array}$ & EaG, D6.1 \\
\hline VOCAT & $\begin{array}{l}\text { Proportion of fifteen-year-olds enrolled in programmes that } \\
\text { give access to vocational studies at the next program level or } \\
\text { direct access to the labour market (2003) }\end{array}$ & EaG, D6.1 \\
\hline EXPSEC & $\begin{array}{l}\text { Expenditure on educational institutions of primary, lower } \\
\text { secondary, and primary education as a percentage of GDP } \\
\text { from public and private sources (2002) }\end{array}$ & $\mathrm{EaG}, \mathrm{B} 2.1$ \\
\hline ENROL & Net entry rates into tertiary education (2003) & $\mathrm{EaG}, \mathrm{C} 2.2$ \\
\hline PRVRSC & $\begin{array}{l}\text { Relative proportion of private sources of funding on institutions } \\
\text { of tertiary education (percentage of total expenditure, 2002) }\end{array}$ & $\mathrm{EaG}, \mathrm{B} .3 .2$ \\
\hline FINAID & $\begin{array}{l}\text { Financial aid to students: public subsidies for households and } \\
\text { other private entities as a percentage of total public expenditure } \\
\text { on tertiary education (percentage of total expenditure on terti- } \\
\text { ary education, 2002) }\end{array}$ & $\mathrm{EaG}, \mathrm{B} .5 .2$ \\
\hline EXPTER & $\begin{array}{l}\text { Expenditure on tertiary educational institutions as a percentage } \\
\text { of GDP from public and private sources (2002) }\end{array}$ & EaG, B2.1 \\
\hline
\end{tabular}

Table A2. Correlations between indicators used in the analysis of education systems

\begin{tabular}{|c|c|c|c|c|c|c|c|c|}
\hline & GENSEC & NUMPRG & VOCAT & EXPSEC & ENROL & PRVRSC & FINAID & EXPTER \\
\hline GENSEC & 1.000 & & & & & & & \\
\hline NUMPRG & -0.477 & 1.000 & & & & & & \\
\hline VOCAT & -0.295 & 0.496 & 1.000 & & & & & \\
\hline EXPSEC & 0.261 & -0.612 & -0.343 & 1.000 & & & & \\
\hline ENROL & 0.275 & -0.672 & -0.221 & 0.431 & 1.000 & & & \\
\hline PRVRSC & 0.531 & -0.162 & 0.191 & -0.054 & 0.240 & 1.000 & & \\
\hline FINAID & 0.268 & -0.699 & -0.314 & 0.302 & 0.460 & 0.050 & 1.000 & \\
\hline EXPTER & 0.464 & -0.580 & -0.242 & 0.466 & 0.399 & 0.445 & 0.345 & 1.000 \\
\hline
\end{tabular}




\section{SPSS Commands}

SPSS commands use to run logistic regression of educational aspirations on ability, parental socio-economic status and gender.

a) commands used to assess the coefficient of determination (Nagelkerke's $R^{2}$ ):

LOGISTIC REGRESSION VAR=COLLEXP

/METHOD=ENTER abil hisei sex

/CONTRAST (sex)=Indicator

/CRITERIA PIN(.05) POUT(.10) ITERATE(20) CUT(.5) .

b) commands used to assess the net effects of parental socio-economic status and ability for descriptive analyses (ABIL and HISEI transformed into quintiles):

split file by cnt2.

LOGISTIC REGRESSION VAR=COLLEXP

/METHOD=ENTER abil5 isei5 sex

/CONTRAST (isei5)=Indicator

/CONTRAST (abil5)=Indicator

/CONTRAST (sex)=Indicator

/CRITERIA PIN(.05) POUT(.10) ITERATE(20) CUT(.5) .

split file off. 